\title{
Portrayal of Pakistan in the New York Times andthe Washington Post: A Study of Editorials during 2008 to 2010
}

\author{
Ghulam Shabir $^{1}$, Tanveer Hussain ${ }^{2}$ and Yasir Waseem Iqbal ${ }^{2 *}$ \\ ${ }^{1}$ ChairmanDepartment of Media Studies, The Islamia University of Bahawalpur, Pakistan \\ ${ }^{2}$ Department of Media Studies, the Islamia University of Bahawalpur, Pakistan
}

\begin{abstract}
This research explores the image of Pakistan in The New York Times and The Washington Post editorials during Feb 2008 to Jan 2010. It found that the overall image of Pakistan remained positive in both newspapers. It based on hypothesis that "the overall ratios of unfavorable coverage about Pakistan would be greater than favorable coverage in The New York Times and The Washington Post" and tested through content analysis and two communication theories (mediaconformity and media framing) are applied. 89 editorials published about Pakistan during proposed period of research in both newspapers in which; $35.47 \%$ coverage remained positive, $32.50 \%$ negative and $31.94 \%$ remained neutral. Moreover: portrayed about Zardari administration, politics of Pakistan, aid for Pakistan, American strategies towards Pakistan, Pak-US relations and Pakistan role in war on terrorism remained positive. The portrayal of Pakistan, Al-Qaida \& Taliban problems of Pakistan and religion remained negative while the portrayal of ISI, indoPak relations\& Kashmir and Afghanistan insurgency and Pak remained neutral.The findings of the research support media conformity theory as; American media follows the American government foreign policies and portrayed positive frame of Pakistan.
\end{abstract}

Keywords: Pakistan; ISI; Zardari

\section{Introduction}

Pakistan image remain controversial throughout her history. It becomes more critical during dictatorship period. It has taken a steep downward after the event of $9 / 11$ and General Musharaf Coup. There are many reasons, which tarnished the image of Pakistan in western world especial in America. Al-Qaida, Taliban, Military Coup and political instability in the Country are the main reasons of poor image of the country in the world.Many sanctions were imposed for the restoration of democracy in Pakistan by The United State of America [1]. American media criticized military coup as well as focused on the restoration of democratic govt.This research designed to investigate the image of Pakistan in the American media during democratic government of President Asif Ali Zardari especially in The daily New York Times and The daily Washington Post.

\section{Brief about Pakistan}

Pakistan emerged on to the world stage on $14^{\text {th }}$ august 1947, after a two pronged struggle; First, for independence from colonial rule and secondly, freedom for the people of Muslim majority areas from looming threat of economic, social and political domination by another people manifestly dismissive of their urge to preserve their separate identity [2].In a sense Pakistan has been Islamic from its inception, indeed it owes its birth to the fact the Islamic feeling of the people wanted to express itself in the form of a state. Islam is a religion of society, and in order to bring the full effect of principles of Islam to a human society. There must be a fully sovereign Islamic community, having the sanctions of a state to implement Islamic law, that's why Pakistan came into exist [3].

\section{Economy}

Pakistan is an underdeveloped country. Having 5-8\% GDP growth rate, $13 \%$ inflation, 464.9 billion dollar purchasing power, $\$ 2.500$ per capita income, $24 \%$ population below poverty line, 55.77 million labor force, $43 \%$ population related to agriculture, $20.3 \%$ related to industry, $36 \%$ population related to services, $15.4 \%$ unemployment rate, 21.46 billion dollar export, and 32.88 billion import and all above data is of 2010 [4].

\section{Foreign policy}

The foreign policy of Pakistan has been determined by national self interests, enlightened or not, as conceived by her leaders. The geo political factor, political aspirations and the need for economic development have played their role of much more importance have been the special factors, viz. the ideology and commitments made during the struggle for Pakistan, the sort of equation established by the Muslim league leaders with the ex-colonial power before and after formation of Pakistan and the mode of achieving Pakistan. Besides, the foreign policy was tailored to Pakistan's domestic needs. It symbolized in particular, the validity of her internal policies and served as a useful distraction from her internal anxieties [5].

\section{Geo strategic location}

Pakistan's geo-strategic location makes it vital to both the super powers \& gives it potentially a decisive role in keeping balance of power in Asia and peace in the world [6].

\section{Brief about America}

The discovery of America did not begin with Christopher Columbus. It began thousands of years earlier when human beings

*Corresponding author: Yasir Waseem Iqbal, Department of Media Studies, The Islamia University of Bahawalpur, Pakistan, Tel: +92-62-9255561; E-mail: samiarahman23@gmail.com

Received September 26, 2013; Accepted February 10, 2014; Published February 15,2014

Citation: Shabir G, Hussain T, Iqbal YW (2014) Portrayal of Pakistan in the New York Times andthe Washington Post: A Study of Editorials during 2008 to 2010. J Mass Communicat Journalism 4: 179. doi:10.4172/2165-7912.1000179

Copyright: ( 2014 Shabir G, et al. This is an open-access article distributed under the terms of the Creative Commons Attribution License, which permits unrestricted use, distribution, and reproduction in any medium, provided the original author and source are credited. 
first crossed an ancient land bridge over the Bering Strait into what is now Alaska and-almost certainly without realizing it-began to people new continent. No one is certain when these migrations began; recent estimates suggest between 12,000 and 14,000 years ago. But some scholars believe the first crossing were much earlier. They were probably a result of the development of new stone tools [7]. The United States had emerged by 1945 as the world's undisputed number one industrial, financial and military power. Washington owned two-thirds of worlds' gold supply, one third of the world's exports, half the world's shipping. The army had billions of services personnel and virtual monopoly on atomic weapons [8]. The traumatic events of September 11, 2001 changed many aspects of American life, not least the nation's sense of its isolation and insulation, from the problems of the rest of the world. It seemed safe to predict that the American people would go forward into their suddenly uncertain future not simply burdened by difficult challenges, but also armed with great wealth, great power, and perhaps most of all with extra ordinary energy and resilience that has allowed the nation throughout its long and often turbulent history to endure, to flourish and to strive continually for a better future [7]. After $9 / 11$ incident America increased aid and reliance on Pakistan to drive out Al-Qaeda and Taliban from Afghanistan. Even she supports military dictatorship of Pakistan to get cooperation in Afghanistan [9].

\section{Pakistan U.S relations}

Pakistan U.S relations remained haphazard from last 64 years. America wants to impose her policies and Pakistan wants to work on equal basis [10]. Pakistan had focused its effort to build a close relationship with the United States much earlier. To compensate for its limited military capability and seeking a shield against a larger and more powerful neighbor, Islamabad reached for an outside protector. The cold war offered the possibility and successive leaders energetically cultivated and America - Pakistani alliance. This astute policy served Pakistan well as the state received economic and military support. Moreover, American support improved Pakistan's political posture as Pakistan became a member of the Baghdad pact (1954-58) and of the south East Asia treaty organization (SEATO; 1955-71). In return, Pakistan's signature on a mutual defense- agreement with Washington in 1959 gave the United States access to facilities to monitor to Soviet Union [11]. 9/11 incident once again compelled both nations, for close relationship. America support even dictatorship to get its goal. America wants to end of Taliban and al-Qaida and Pakistan want to get more and more economic aid. That's why they came closer and became ally "war on terror" [12]. In Mushraf regime, American government and media highlight Pakistan as a positive and courageous country after Mushraf becoming U.S alley, American government remove sanctions and provide aid for military and civil assistance and American media portray Mushraf as modern, civilized, pro western, liberal leader, progressive, pro George Bush, courageous and one who deal with Islamic fundamentalists [13].

Now a day's Pakistan- U.S relations are in great trouble. America criticized Pakistan's; ISI, army, nuclear program, role in war on terror, talban's \& al-Qaida's presences in Pakistan and Pakistan criticize American's drown attacks, attitude toward Pakistan, policy of unequal relations and mistrust on Pakistan. But it is reality that close relation with one another are in the favor of both countries.

\section{Review of Literature}

Wanta said previous researches shows international news coverage in the U.S media has a direct influence on U.S public opinion. He also found that it has a strong effect on public opinion, specially related to international conflict. Graber said government view influence the media content. Keith [14] concluded in his research, "The U.S media 'discovers' Pakistan's Mushraf is a dictator-why now" that American media criticized Mushraf regime and stressed on the post Mushraf Pakistan. Shahzad concluded in his research article "American mass media and foreign policy: A study about the white house and main stream print media and electronic media in effecting the process of development of American foreign policy". That American mass media work according to United State foreign policy and some time it become helpful in formulation of foreign policy.

Wilfred [15] described that the United States and western media mostly criticized the third world countries for the limited coverage. Smith [16] concluded in his research "Reflecting the real world? How British TV portrayed developing countries in 2005" that British media highlight the third world countries as a hopeless and portrayed negative aspect of these countries. Mugees [17] explain in his article "Image of Iran in the western media" that western media representing Islam as a stereotype and violent religion, this representation creating misunderstanding between Christianity and Islam. Riffe [18] defined in his article that media often portrayal foreign country under the host countries dominant ideology.

\section{American media portrayal related to foreign countries}

The portrayal of other countries construct by any country has a prime importancein the world. Through these images someone can analyze the relations of the nations [19]. The American media portrayed foreign countries in the context of economy, social relations, developments, military, culture, political terrorism and peace. Yu and Riffe [20] concluded in their research "Coverage of china's national leaders Chiang and Mao in American newspapers" that U.S media present the image of foreign countries on the behalf of its national interests and other's countries status. This image changed time to time as relations of both countries changed. Dorman [21] explained in his research "The U.S press coverage on Iran" that U.S media covered Iran differently in different era. During shah's regime it portrayed positive and after revolution it portrayed negative and criticized Khomeini on export of terrorism. Mechensey [22] described in his research "The news media and world war III" that U.S media protect the national interest during world war III. He gave the example of $\mathrm{CNN}$ and proved that the U.S media cover the event which just serves the American interest. Park [23] concluded in his research "Coverage of Korea and Japan in U.S TV frames" that American media portrayal in the favor of American economy interest. It presented Korea in a chaos while Japan in a democracy frame. Park clearly described that where the American economy interest involved the U.S media cover as a positive frame.

\section{Methodology of Research}

This study analyzes the editorial coverage of The New York Times and The Washington Post about the Portrayal of Pakistan during 2008-2010. Pakistan positioned itself as one of the four fastest growing economies in the Asian region during 2000-07 with its growth averaging 7.0 per cent per year for most of this period. As a result of strong economic growth, Pakistan succeeded in reducing poverty by one-half, creating almost 13 million jobs, halving the country's debt burden, raising foreign exchange reserves to a comfortable position and propping the country's exchange rate, restoring investors' confidence and most importantly, taking Pakistan out of the IMF Program. These facts were acknowledged by the present government in a Memorandum of Economic and Financial Policies (MEFP) for 2008/09-2009/10, while signing agreement with the IMF on November 20, 2008. The document 
clearly (but grudgingly) acknowledged that "Pakistan's economy witnessed a major economic transformation in the last decade. The country's real GDP increased from $\$ 60$ billion to $\$ 170$ billion, with per capita income rising from under $\$ 500$ to over $\$ 1000$ during $2000-07 "$. It further acknowledged that "the volume of international trade increased from $\$ 20$ billion to nearly $\$ 60$ billion. The improved macroeconomic performance enabled Pakistan to re-enter the international capital markets in the mid-2000s. Large capital inflows financed the current account deficit and contributed to an increase in gross official reserves to $\$ 14.3$ billion at end-June 2007.

\section{Research Design}

The research chooses content analysis as a research design. While "content analysis is a method of studying and analyzing communication in a systematic objective and quantitative manner for the purpose of measuring variable". All editorials about Pakistan of The New York Times \&The Washington Post from Feb 1, 2008 to Jan 31, 2010 are considered as the universe of the study.

The both newspapers published whole editorials on following categories during proposed period of research.

- Taliban and Al-Quaida (Islamic Militant Moment)

- War on Terror

- Zardari Administration.

- Role of ISI

- Pakistan armed forces

- Nuclear issues.

- Problems of Pakistan

- Pak-U.S relations

- Religion

- Politics

- Aid

- American Strategies

- Indo-Pak relations and Kashmir issue

- Afghan Insurgency \& PAK

- Women condition in Pakistan

- Others

The Pakistan portrayal has been analyzed according to these three categories slant.

- Favorable

- Unfavorable

- Neutral

Portrayal of Pakistan in The New York Times and The Washington Post (Figure 1).

\section{Conclusion}

This research started on the base of many research questions. But main question remained throughout the research about the slant of coverage about Pakistan. Gathered data shows that the portrayal of

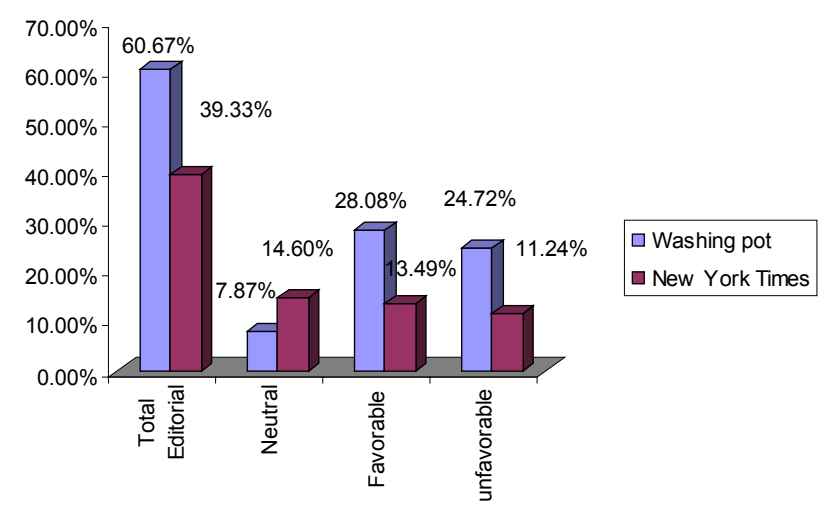

Figure 1: Portrayal of Pakistan in The New York Times and The Washington post.

Pakistan during Feb 2008 to Jan 2010 in The New York Times and The Washington Post remained positive which proved that the American media support the American govt. foreign policies. The finding shows that the both newspapers published 89 editorials comprised on 767 paragraphs about Pakistan in proposed period of research. The Washington Post published 54 (60.67\%) editorials; comprised on 449 paragraphs while The New York Times published 35 (39.33\%) editorials; comprised on 318 paragraphs which shows that The Washington post give more editorial coverage to Pakistan than The New York Times. The data shows that The Washington post published 25 (28.08\%) favorable editorials; comprised on 174 paragraphs, 22 (24.27\%) unfavorable editorials; comprised on 157 paragraphs and 7 (7.87\%) neutral editorials; comprised on 118 paragraphs while The New York Times published 12 (13.49\%) favorable editorials; comprised on 98 paragraphs, 10 (11.24\%) unfavorable editorials; comprised on 93 paragraphs and 13 (14.60\%) neutral editorials; comprised on 127 paragraphs. The overall editorial coverage of The Washington post about Pakistan during proposed period of research remained positive while in New York Times it remained neutral. Both newspapers published $41.57 \%$ positive, $35.91 \%$ negative and $22.47 \%$ neutral editorials. So these results shows that the overall ratio of coverage about Pakistan remained positive and it disproved the hypothesis. "The overall ratio of unfavorable coverage about Pakistan would be greater than the favorable coverage in The New York Times and The Washington Post".

\section{Discussion}

The positive portrayal of Pakistan in the two American elite newspapers shows that the American media support American government towards Pakistan. In the end session of General Musharaf era: the American media stressed on the restoration of democracy in Pakistan. It was criticizing the Musharaf policies and forced American govt to away from Musharaf. After the removal of Mushraf and restoration of democracy in Pakistan; the American media specially The New York Times and The Washington Post support Pakistani democratic govt. Both newspaper portrayed positive image of Zardari administration, politics of Pakistan and Aid for Pakistan.Another reason of positive portrayal remained cooperation of both governments on war on terror. America declare Pakistan main alley in war on terror and Pakistan's important geographic location in the region made her necessary for America. To support the American government foreign policies; especially towards Pakistan, the American media portrayed Pakistan image as its government want. It portrayed positive frame of American strategies towards Pakistan, Pakistan role in war on terror 
Citation: Shabir G, Hussain T, Iqbal YW (2014) Portrayal of Pakistan in the New York Times andthe Washington Post: A Study of Editorials during 2008 to 2010. J Mass Communicat Journalism 4: 179. doi:10.4172/2165-7912.1000179

Page 4 of 4

and Pak-U.S relations while these newspapers portrayed neutral image of Pakistan in; afghan insurgency, ISI and Pak-India relations. Both newspapers portrayed negative image of Pakistan in; nuclear issues, al-Qaida \& Taliban, problems of Pakistan, religion extremism and Pak-Army. These are the issue which ever remained negative in the American media. In the light of discussion we can concludes that the media conformity theory supported by the findings of research towards Pakistan. The government of America adopted pro Pakistani policy and the American media follow it and framed positive image of Pakistan.

\section{Suggestions}

American media portrayed differently in different era's; when its government become alley with Pakistan it going to start positive coverage but some main issues portrayed negative in any condition. It is the suggestion from researcher that American media should portrayal neutral image about the sensitive issues; like nuclear issues, problems of Pakistan, about the roots of al-Qaida \& Taliban, Pak army and Islam. It should not act upon the long term strict agenda on these issues. There should be flexibility and neutrality. The issues should be covered on merit. It should not just fallout of their governments about foreign countries.American media shaped the world opinion and issues to resolve. It should be free and fair about all events and issues. So that the opinion of the world can be make plain and positive about other countries.

\section{References}

1. Zia M (2009) United States, Pakistan: The decade ahead, Pakistan.

2. Sattar (2007) Pakistan's foreign policy. Oxford: university press, Pakistan.

3. Chaudhary (2000) Pakistan transition from military to civilian rule. Lahore: Alllahwala printers, Pakistan.
4. Pakistan year book (2012) $40^{\text {th }}$ edition, Pakistan.

5. Singh S (1977) Pakistan's foreign policy. Lahore: Universal books, Pakistan.

6. Economy of Pakistan (2010) Pakistan.

7. Brinkley, Alan (2003) American history: a survey, eleventh edition, New York: McGraw Hill, USA.

8. Ram R (1983) Soviet policy towards Pakistan. New Delhi: Chand and Co.

9. Perkovich G (2011) Stop enabling pakistandangrous dysfunction, Pakistan.

10. Fridman (2009) Pakistan-U.S. Relations.

11. Shirin (1998) India, Pakistan and the United States. Lahore: vanjuard books pvt Itd, Pakistan.

12. Twining D (2011) U.S.-Pakistan relations: Is this the end of affairs?

13. Sirraj (2006) A research report on Image of Pakistan in the U.S media: exploring news framing.

14. Keith (2007) The U.S media discovered Pakistan's mushraf is a dictator-why now.

15. Wilfered (1993) The United States and the western media.

16. Smith (2006) Reflecting the real world? How british TV portrayal developing countries in 2005.

17. Mugees-ud-Din S (1995) Image of Iran in western media, Iran Shenagi". International quarterly journal winter 4.

18. Riffe (1998) Portrayal of foreign country and dominant ideology.

19. McCracken K (1987) Australia and Australians: View from New York Times. Journalism Quarterly 64: 183-189.

20. Yu, Riffe (1989) Coverage of china's national leaders Chiang and Mao in American newspapers.

21. Dorman A (1987) The US press coverage on Iran.

22. Mechensey (2002) The News media and world war III.

23. Park (2003) Coverage of Korea and Japan in US TV frames. 